dents that we can grade to the precision of discriminating between different answers by a single point. This not infrequently results in histrionics, manipulation, mau-mauing, and general unpleasantness. I doubt seriously that anyone can grade an essay much more accurately than within half a grade. I have also discovered that most students end up with mid-term and final scores that fall within a range of one-half grade of each other, suggesting that my grading is reasonably accurate. Those falling outside that range I usually recheck to see if I have made an error.

Several tactics address these problems. One can simply assign letter grades only to essay exams. Upon returning the exams I always go over in some detail what would constitute an "A" answer to each question. I make it mandatory for all students requesting a reevaluation of their exam to submit a one-page written argument as to why they deserve that change. I reread their exam and respond in writing. If the student is still unhappy after my response, then I will meet personally with that individual.

If I am unwilling to change the grade and the student is adamant, then I have occasionally resorted to the cruel expedient of having the student read the disputed answer to me aloud. That's usually all it takes to end the dispute. I have also found it helpful to photocopy excellent essays, sans student name, to show to stu- dents with queries about their grades. This is more effective than having them read my own template because it demonstrates what one of their colleagues was in fact able to achieve, not merely what I expected. Another approach is to enforce a 24-to 48-hour "cooling off" period before students may come in to discuss their exam results. On the other hand, given the relative imprecision attendant to grading essays, I am usually willing to grant a few more points.

For students who genuinely wish to improve their performance on the next exam, I do not insist on any of the above; I see them directly. If the course has graders or teaching assistants, students are required first to go through the process with them, before seeing me, in order to minimize the opportunity to play off instructor against assistant. Except for cases in which errors were made in computation, I do not change grades after grade reports have been turned into the registrar.

Following a practice I learned as an undergraduate, I ask those students who have done especially well on an exam to stop by my office hours to chat. This permits me to extend my felicitations on their performance, especially important for students in large, anonymous classes. It gives me the chance to see my best students, helping to balance those more frequent interactions with students who only have problems.

\title{
Public Choice in Political Science: We Don't Teach It, But We Publish It*
}

\author{
Jay Dow, University of Texas at Austin \\ Michael Munger, University of North Carolina at Chapel Hill
}

The study of political science has been substantially transformed by the work of public choice scholars over the past 40 years. Such works as Arrow (1951, 1963), Buchanan and Tullock (1962), Black (1958), Downs (1957), Niskanen (1971), Olson (1965), Riker (1962), Sen (1970), and Stigler (1971) now appear extensively in the references of articles published in a variety of our professional journals. We were interested in discover- ing how extensively the public choice approach is being pursued in graduate political science programs in the United States. Our focus is mainly on programs in American politics, because this field more than any other has been the forum for work in public choice. To foreshadow our conclusions, the results tend to indicate that public choice in political science is seen as an offshoot, or related discipline, rather than as a

\section{A Few Last Words}

I have touched on some of the difficult problems associated with exams and grading in this less than perfect world in which we teach. I do not pretend to have surveyed them exhaustively nor to have provided any definitive solutions. Indeed, I do not believe there are solutions, only palliatives that may reduce the violence of endemic problems. The suggestions made here result from my own trial and error (with emphasis on the latter) experience with undergraduate courses in several large public universities. Others will no doubt have additional, and perhaps more effective, suggestions, which fit more closely the contours of their own corporate cultures. I do not think I am overly pessimistic in asserting that these problems will never go away, nor excessively optimistic that we can find effective mechanisms for their redress.

\section{Note}

*My thanks for their helpful comments on an earlier version of this paper to Gregory Caldeira, Nelson Polsby, Richard Sklar, and John Zaller.

\section{About the Author}

Donald Chisholm is a member of the Department of Political Science at the University of California, Los Angeles. substantive field in and of itself. The authors of this paper feel this is a mistake, and hope to persuade the reader.

We offer two arguments for this position. First, as we demonstrate later, a significant proportion of publication in our discipline's professional journals take a public choice perspective. Students with no introduction to the jargon and methods of this approach are needlessly 
excluded, if only from offering valid and informal criticisms. Publication alone is not a sufficient cause, however, because such a claim only extends the question to why such work is published. This raises the second reason: the public choice approach offers an alternative, internally coherent set of answers to the questions political scientists study. It also provokes new questions, such as the means by which institutional arrangements mitigate the problems of instability that pervade mechanisms for arriving at collective decisions. Students unschooled in even basic social choice theory, for example, may be mystified by the problems of comparing legislatures in different U.S. states or different countries. Variations in outcomes attributed to cultural or sociological differences may be explicable in terms of the mechanisms of public choice, be they voting rules or bureaucratic process. Students need the formal knowledge of institutions that public choice provides.

The journals are performing their task of disseminating information quite well; it is our job as teachers to ensure the material makes it from the journals to the students.

\section{Political Science Graduate Programs and Public Choice}

Richard F. Winters' 1988 report to the American Political Science Association, "Graduate Instruction in American Politics" (hereinafter "GIAP") contained a wealth of information on graduate programs. Its utility for our purposes lies in its survey of syllabi of 19 top "core" sequences in American politics in an effort to determine what readings are most commonly assigned.

The results are reproduced in Table 1 . Only the most-cited 16 (37\% or more schools assigning) are included. Two of the top three, Downs (1957) and Olson (1965), are classics of the public choice approach but the next reading clearly within the public choice tradition is Fiorina (1974). At best, three of the top 16 readings are public choice oriented, and there are many obvious omissions (e.g., Buchanan and Tullock,
1962 is nowhere to be seen). Still, the reason why public choice readings may not appear well represented in the political science graduate curriculum could lie in the generality of the listing. Dividing the overall curriculum into discrete topics may provide a better picture.

\section{Specific Topics: Voting, Interest Groups and Congress}

We made an informed but still subjective choice of the topics in political science where public choice has made its most significant contributions. The first is voting, and

. . . public choice in

political science is seen as

an offshoot, or related discipline, rather than as a substantive field in and of itself.

the readings in Table 2 surprised us. Of all the topics in which voting is taught (values, participation, public opinion, models) only in "models" is there any discernible public choice influence (Fiorina 1981; and some readings in Niemi 1976, 1984).
Downs (1957) is taught as a sidelight or curiosity, and does not appear in this section. Riker and Ordeshook (1968), the origin of the "rational model" of voting, does not appear at all.

The interest groups readings in Table 3 are more encouraging, but only marginally so. Public choice "challenges" (Olson 1965; Stigler 1971) to traditional group theory are taught as a coherent subfield. Still, this work is treated as an historical curiosity to which there is a modern (i.e., "correct") response such as the work of Terry Moe (1980). The major "modern" public choice view of interest groups is not visible, for no articles on rent-seeking appear here, or for that matter anywhere in GIAP. By comparison to the other subfields, interest groups must be counted as at least a marginal success, however: Olson and Stigler have had some impact in redirecting the literature.

Finally, as one might expect, the greatest contemporary successes of public choice appear in the study of Congress, as Table 4 illustrates. The approach is well-represented in legislative elections (Fiorina 1974; Kuklinski 1978; Tufte 1975), and organizing and leading Congress (Fiorina 1977; Denzau and Mackay 1983). Further, the policy and oversight literature appears to have had some public choice influence (Denzau and Munger 1986; McCubbins and
TABLE 1.

Most Frequently Cited Readings in 19 Graduate American Politics Courses

\begin{tabular}{llc}
\hline Author & Book/Article & $\begin{array}{c}\% \text { of Schools } \\
\text { Assigning }\end{array}$ \\
\hline R. E. Neustadt & Presidential Power & 79 \\
Anthony Downs & Economic Theory of Democracy & 68 \\
Mancur Olson & Logic of Collective Action & 63 \\
Angus Campbell, et al. & American Voter & 58 \\
Phillip Converse & "Nature of Belief Systems in Mass Public" & 53 \\
Richard Fenno & Congressmen in Committees & 47 \\
Theodore Lowi & The End of Liberalism & 47 \\
David Mayhew & Congress: The Electoral Connection & 47 \\
Nelson Polsby & "Institutionalization of the U.S. House" & 47 \\
Robert Dahl & A Preface to Democratic Theory & 42 \\
Morris Fiorina & Retrospective Voting & 42 \\
E. E. Schattschneider & Party Government & 42 \\
David Truman & The Governmental Process & 42 \\
Hugh Heclo & Government of Strangers & 37 \\
James Sundquist & Dynamics of the Party System & 37 \\
Aaron Wildavsky & Politics of the Budgetary Process & 37 \\
\hline
\end{tabular}

Source: Richard Winters, "Graduate Instruction in American Politics," Table 4, p. 11, presented at the American Political Science Association meetings, September 2, 1988. Working Paper Series of the Nelson A. Rockefeller Center for the Social Sciences at Dartmouth College. 
Schwartz 1984; Weingast and Moran 1983). In addition to enjoying these individual successes, an entire section on "institutional analysis" appeared on a few reading lists.

Still, even for the "best" subsection (Congress) public choice has made only minor inroads into American politics: Weingast and Moran (1983) and Fiorina (1977) each appeared on four reading lists, with all the others appearing less often. The sample of 19 universities represents schools we believe to be more likely than average to be sympathetic; a reasonable extrapolation is that most schools have no public choice readings at all. Further, those that do are likely to go no further than Downs (1957) and Olson (1965). While we have no direct evidence on this assertion, we do have a broader sample of university course offerings of 62 major political science departments.

\section{The Course Offerings}

We surveyed the graduate course offerings of 62 top political science departments in the United States by examining their most recent catalogs. Using the most liberal possible criteria for being counted as a "public choice" course, we then contacted each department by letter to determine what readings were assigned in these courses, what topics are included, and when the course was last taught. This information is available from the authors; the results we present are in an aggregate form designed to provide an overview.

Some preliminary conclusions can be drawn from the course offerings themselves. We counted such things as "international political economy," and "electoral behavior and party strategy" as public choice courses. For example, one university (we won't say which) even has an offering on "Politics and the Libido." We counted it; such creativity in the service of science simply cannot go unrewarded. With this significant bias in mind, consider Table 5. More than half the sample (35/61) have one or fewer courses that could count as public choice even by the most tortured definition. Students at most universities can therefore acquire a $\mathrm{Ph} . \mathrm{D}$. in political science

TABLE 2.

Most Cited Readings on Voting

\begin{tabular}{|c|c|c|}
\hline Author & Book/Article & $\begin{array}{l}\text { \# of Schools } \\
\text { Assigning }\end{array}$ \\
\hline \multicolumn{3}{|l|}{ American Values and } \\
\hline J. Sullivan, et al. & Political Tolerance and American Democracy & 4 \\
\hline G. A. Almond, et al. & The Civic Culture & 3 \\
\hline H. McCloskey & "Issue Conflict and Consensus. . ." (1960) & 3 \\
\hline F. Greenstein & "The Benevolent Leader Revisited" (1975) & 2 \\
\hline W. Lippmann & Public Opinion & 2 \\
\hline H. McCloskey, et al. & The American Ethos & 2 \\
\hline A. Miller & $\begin{array}{l}\text { "Political Issues and Trust in Government" } \\
\text { (1974) }\end{array}$ & 2 \\
\hline D. Prothro and Griggs & "Fundamental Principles of Democracy" (1960) & 2 \\
\hline \multicolumn{3}{|l|}{ Participation: } \\
\hline S. Verba and N. Nie & Participation in America & 5 \\
\hline R. Wolfinger, et al. & Who Votes & 5 \\
\hline P. Abramson, et al. & $\begin{array}{l}\text { "The Decline of Electoral Participation in } \\
\text { America" }\end{array}$ & 2 \\
\hline R. Axelrod & $\begin{array}{l}\text { "Where the Vote Comes From" }(1972,74,78 \text {, } \\
\text { 82) }\end{array}$ & 2 \\
\hline R. Brody & $\begin{array}{l}\text { "Puzzle of Participation" in A. King, New } \\
\text { American Political System }\end{array}$ & 3 \\
\hline D. Rae & Political Consequences of Electoral Laws & 2 \\
\hline \multicolumn{3}{|c|}{$\begin{array}{l}\text { Party, Public Opinion and } \\
\text { the American Voter: }\end{array}$} \\
\hline A. Campbell, et al. & The American Voter & 11 \\
\hline P. Converse & "The Nature of Belief Systems in Mass Publics" & 10 \\
\hline V. O. Key & "A Theory of Critical Elections" & 5 \\
\hline P. Abramson & Political Attitudes in America & 3 \\
\hline B. Berelson et al. & Voting & 3 \\
\hline V. O. Key & Politics, Public Opinion, and Democracy & 2 \\
\hline V. O. Key & The Responsible Electorate & 3 \\
\hline \multicolumn{3}{|l|}{$\begin{array}{l}\text { Changing Models of the } \\
\text { Vote: }\end{array}$} \\
\hline M. P. Fiorina & Retrospective Voting & 8 \\
\hline N. Nie, et al. & The Changing American Voter & 6 \\
\hline R. Niemi, et al. & Controversies in Voting Behavior & 6 \\
\hline W. D. Burnham & $\begin{array}{l}\text { Critical Elections: The Mainsprings of American } \\
\text { Politics }\end{array}$ & 4 \\
\hline A. Campbell, et al. & Elections and the Political Order & 4 \\
\hline D. Kinder, et al. & “'Sociotropic Politics. . ." (1981) & 3 \\
\hline G. Markus, et al. & $\begin{array}{l}\text { "A Dynamic, Simult, Equation Model of } \\
\text { Electoral Choice" }\end{array}$ & 3 \\
\hline B. Page, et al. & $\begin{array}{l}\text { "Reciprocal Effects of Policy Preferences. . ." } \\
\text { (1979) }\end{array}$ & 3 \\
\hline W. D. Burnham & Current Crisis in American Politics & 2 \\
\hline G. Kramer & "Short-term Fluctuations. . ." (1971) & 2 \\
\hline P. Natchez & "Images of Voting”' (1970) & 2 \\
\hline N. Nie, et al. & "Mass Belief Systems Revisited" & 2 \\
\hline J. Sullivan, et al. & $\begin{array}{l}\text { "Ideological Constraints in the Mass Public" } \\
\text { (1978) }\end{array}$ & 2 \\
\hline
\end{tabular}

Source: Richard Winters, "Graduate Instruction in American Politics," Table 3, pp. 13-14, presented at the American Political Science Association meetings, September 2, 1988. Working Paper Series of the Nelson A. Rockefeller Center for the Social Sciences at Dartmouth College.

and be exposed to no public choice at all.

At the other end of the scale, four schools (Rochester with 7, Texas with 7, California Institute of Technology with 6 and Oregon with 5) have at least a core curriculum. Unfortunately, at Oregon these courses are now rarely taught, and $\mathrm{Cal}$ Tech is (argu- ably) not a political science department. Texas has maintained the majority of its curriculum despite a reduction in public choice faculty. This leaves us with Rochester, and to a lesser extent Texas, as the centers of public choice education within political science. Put more bluntly, it isn't that Rochester and Texas are 
the best, it is that they are the only political science departments where public choice is taken seriously.

\section{Conclusion}

Our conclusions are mostly pessimistic about the status of graduate training in public choice in political science: by and large, there isn't any. Of all the readings in American politics graduate courses, the only section where modern public choice has made significant inroads is in the study of Congress. No graduate programs except for Rochester and Texas have a significant public choice field on other than an ad hoc basis. The fact that some schools offer a joint program with their economics department is of limited solace, because mainstream economists often lack any significant appreciation of the importance of institutions. ${ }^{2}$ For now, at least for pedagogy at the graduate level, public choice remains primarily economists studying political science. We believe this is a mistake both for our students and for the discipline as a whole.

The odd thing is that the referees and editors of the major journals appear also to believe that public choice is important. This divergence between what we teach our students is important in their graduate training and what we reveal to be important in terms of salary, promotion, and professional respect is unfortunate. The conflict must ineluctably reduce in students' minds the legitimacy of the journals, the graduate education, or both.

In order to test our perception that

\section{Students at most}

universities can therefore

acquire a Ph.D. in political science and be exposed to no public choice at all.

professional journals contain a significant number of public choice articles, we surveyed four major journals (American Journal of Political Science, American Political Science

TABLE 3.

Most Cited Readings on Interest Groups

\begin{tabular}{|c|c|c|}
\hline Author & Book/Article & $\begin{array}{l}\text { \# of Schools } \\
\text { Assigning }\end{array}$ \\
\hline \multicolumn{3}{|l|}{$\begin{array}{l}\text { Classical Interest Group } \\
\text { Analysis: }\end{array}$} \\
\hline D. Truman & The Governmental Process & 8 \\
\hline E. E. Schattschneider & The Semisovereign People & 6 \\
\hline \multicolumn{3}{|l|}{ Modern Challenges: } \\
\hline M. Olson & The Logic of Collective Action & \\
\hline G. Stigler & "Theory of Economic Regulation" (1971) & 3 \\
\hline \multicolumn{3}{|l|}{ Response: } \\
\hline J. L. Walker & $\begin{array}{l}\text { "The Origins and Maintenance of Interest } \\
\text { Groups in America" (1983) }\end{array}$ & 6 \\
\hline J. Q. Wilson & Political Organizations & 4 \\
\hline T. M. Moe & The Organization of Interests & 3 \\
\hline R. Salisbury & $\begin{array}{l}\text { "An Exchange Theory of Interest Groups" } \\
\text { (1969) }\end{array}$ & 3 \\
\hline K. Schlozman, et al. & $\begin{array}{l}\text { Organizational Interests and American } \\
\text { Democracy }\end{array}$ & 3 \\
\hline T. Gais, et al. & "Interest Groups, Iron Triangles. . ." (1984) & 2 \\
\hline M. Lipsky & "Protest as a Political Resource" (1968) & 2 \\
\hline T. M. Moe & "The New Economics of Organization" (1984) & 2 \\
\hline K. Schlozman, et al. & Injury to Insult & 2 \\
\hline
\end{tabular}

Source: Richard Winters, "Graduate Instruction in American Politics," Table 3, p. 14, presented at the American Political Science Association meetings, September 2, 1988. Working Paper Series of the Nelson A. Rockefeller Center for the Social Sciences at Dartmouth College.

Review, Journal of Politics, and Legislative Studies Quarterly). One might quarrel with our sample, but we make no claim that these are the "best" journals (whatever that even means). Rather, we simply claim that these journals together represent a significant forum for the dissemination of knowledge in the study of American politics. Our criterion for what constitutes a "public choice" article is here as conservative as it was liberal earlier in judging graduate courses. Selections were primarily limited to theory papers; empirical work was counted only if it had a clear theoretical basis in the method of public choice, based on the method itself and the paper's references. In fact, we relied heavily on the references in every case, for they indicate the literature the author(s) herself thinks is important. We excluded work on the "political business cycle" and any article whose title contained the phrase "The Political Economy of. ..." We intend no slight; rather, we seek to bias our measure in favor of understating public choice's influence.

Our results are presented in Table 6. Even using this conservative selection criterion, the proportion of public choice articles in the American
Journal and the Review is approximately one-quarter. While the percentage is lower (around 10 percent) for the $J O P$ and $L S Q$, it is apparent that public choice articles are being selected as worthy of a significant proportion of the pages we all rely on for information about the state of political knowledge. Taking the four journals together, the proportion overall is nearly one-fifth. If this is what we publish, and use as a professional basis for prestige and an institutional basis for remuneration, should we not at least give our students access to this material in graduate school?

We believe the answer is yes. One could speculate about why so few graduate curricula include a substantial public choice component, with the most likely explanation being that the work is still relatively new. A second explanation is that public choice theorists themselves (with the exceptions of William Riker and a few others) have made only desultory efforts to address the broader audience we hope this work will reach. Regardless of the reason, the work will continue to be inaccessible and mysterious to the average student unless we do a better job of providing them the tools to apprehend it. 
TABLE 4.

\section{Most Cited Readings on Congress}

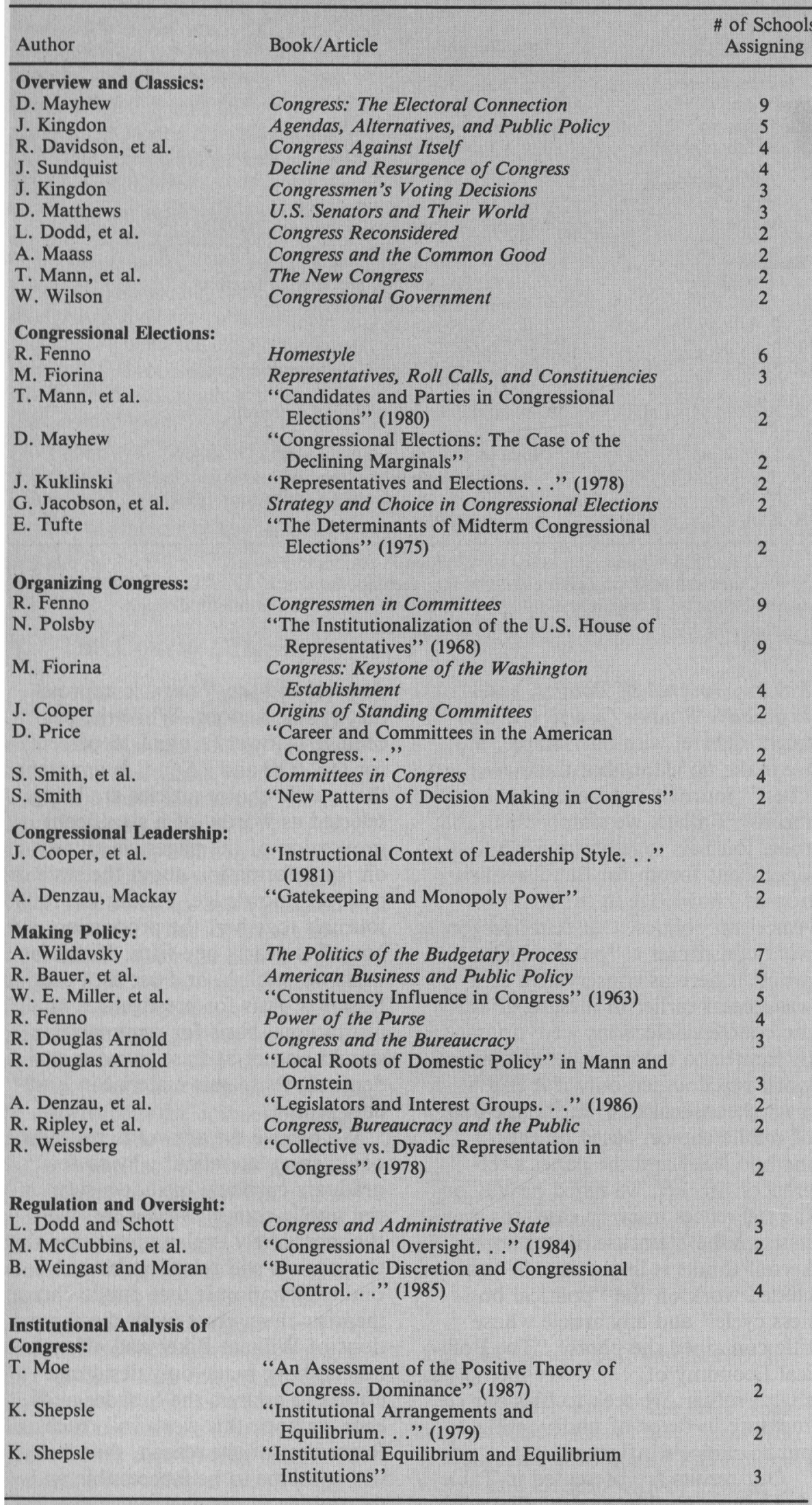

Source: Richard Winters, "Graduate Instruction in American Politics," Table 3, pp. 15-16, presented at the American Political Science Association meetings, September 2, 1988. Working Paper Series of the Nelson A. Rockefeller Center for the Social Sciences at Dartmouth College.

\section{Notes}

*Paper presented at the annual meetings of the Public Choice Society, Tucson, Arizona, March 1990. We wish to thank John Carter, James Enelow, William Keech, and William Mitchell, as well as conference participants Dennis Mueller and Gordon Tullock at Public Choice, for helpful comments on an earlier draft. Any errors of interpretation or presentation are of course ours alone.

1. The graduate programs surveyed in the Winters paper are: American University, University of California at Berkeley, California Institute of Technology, University of Cincinnati, Claremont Graduate School, Cornell University, University of Delaware, Emory University, University of Florida, University of Georgia, Harvard University, Indiana University, University of Iowa, University of Michigan, University of Minnesota, University of Nebraska, Ohio State University, Stanford University, University of Texas at Austin.

2. It is a measure of the success of the program created by William Riker and others at Rochester that the Rochester economics department actually sends its students to take classes in social choice and game theory from the political science department, an arrangement without precedent so far as we know.

\section{References}

Arrow, Kenneth. 1951. Social Choice and Individual Values. New York: John Wiley and Sons. (Revised Edition, 1963).

Black, Duncan. 1958. The Theory of Committees and Elections. Cambridge: Cambridge University Press.

Buchanan, James, and Gordon Tullock. 1962. The Calculus of Consent. Ann Arbor: The University of Michigan Press.

Denzau, Arthur, and Robert J. Mackay. 1983. "Gatekeeping and the Monopoly Power of Committees: An Analysis of Sincere and Sophisticated Behavior." American Journal of Political Science 27: 740-761.

Denzau, Arthur, and Michael C. Munger. 1986. "Legislators and Interest Groups: How Unorganized Interests Get Represented." American Political Science Review 80: 89-106.

Downs, Anthony. 1957. An Economic Theory of Democracy. New York: Harper and Row.

Fiorina, Morris P. 1974. Representative, Roll Calls, and Constituencies. Lexington: Lexington Books.

1977. Congress: Keystone of the Washington Establishment. New Haven Yale University Press.

1981. Retrospective Voting in American National Elections. New Haven: Yale University Press.

Kuklinski, J. 1978. "Representatives and Elections: A Policy Analysis." American Political Science Review 72: 165-177.

McCubbins, Mathew and Thomas Schwartz. 1984. "Congressional Oversight Overlooked: Police Patrols versus Fire Alarms." American Journal of Political Science 28: 165-179. 
TABLE 5.

Public Choice Courses Taught, Survey of 62 Major Departments

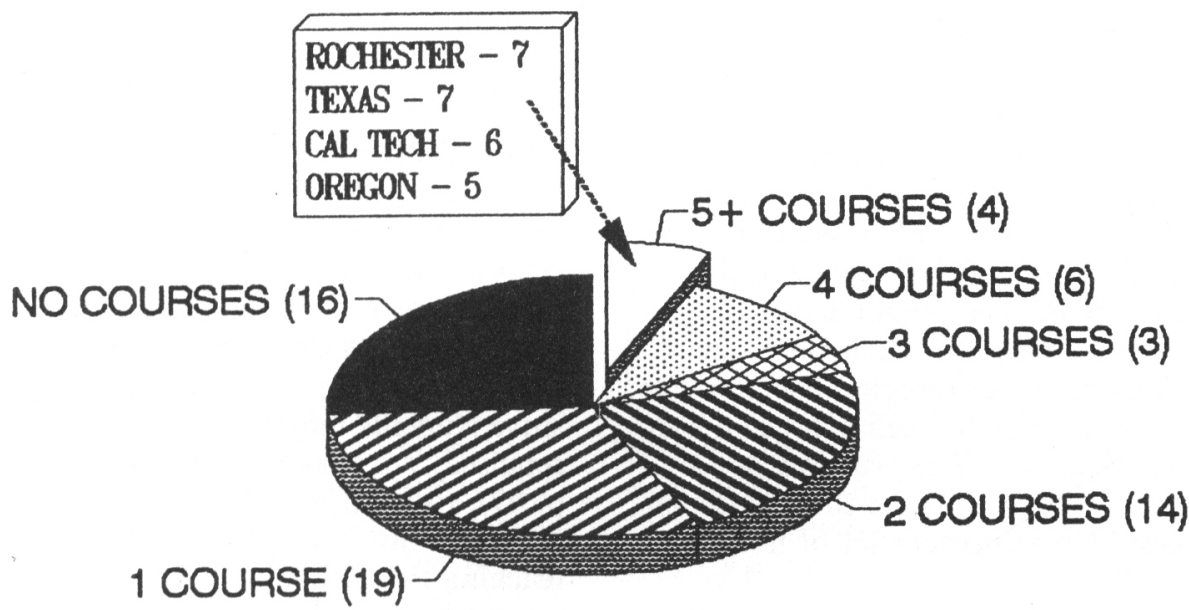

Source: Information collected by the authors from catalogs and course syllabi.

TABLE 6.

Public Choice Articles Published, Survey of Four Major Journals

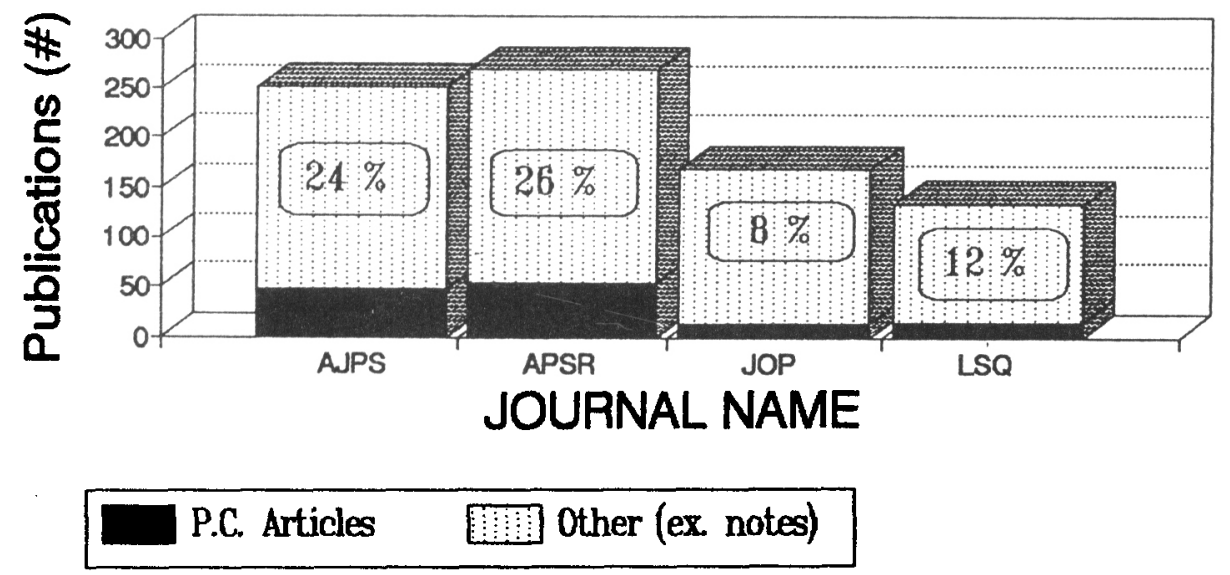

Journals: AJPS = American Journal of Political Science; APSR $=$ American Political Science Review; JOP = Journal of Politics; LSQ = Legislative Studies Quarterly.

Source: Survey by authors.
Moe, Terry M. 1980. The Organization of Interests. Chicago: The University of Chicago Press.

Niemi, Richard and Herbert F. Weisberg. 1976. Controversies in Voting Behavior. San Francisco: W. H. Freeman and Co. (2nd ed., Washington, DC: Congressional Quarterly Inc., 1984).

Olson, Mancur. 1965. The Logic of Collective Action. Cambridge: Harvard University Press.

Riker, William. 1962. The Theory of Political Coalitions. New Haven: Yale University Press.

Riker, William and Peter Ordeshook. 1968. "A Theory of the Calculus of Voting." American Political Science Review 62: 25-42.

Sen, Amartya. 1970. Collective Choice and Social Welfare. San Francisco: HoldenDay.

Stigler, George. 1971. "The Theory of Economic Regulation." Bell Journal of Economics and Management Science 2 (Spring): 3-19.

Tufte, E. 1975. "The Determinants of Midterm Congressional Elections." American Political Science Review 69: 812-826.

Weingast, Barry and Mark Moran. 1983. "Bureaucratic Discretion or Congressional Control: Regulatory Policy Making by the Federal Trade Commission." Journal of Political Economy 91: 765-800.

Winters, Richard. 1988. "Graduate Instruction in American Politics." Nelson A. Rockefeller Center for the Social Sciences Working Paper, and Report to the American Political Science Association.

\section{About the Authors}

Jay Dow is a Ph.D. candidate in government at the University of Texas at Austin, working on a dissertation investigating a spatial model of the 1989 Chilean national elections.

Michael Munger is an assistant professor at the University of North Carolina at Chapel Hill. He is the coordinator of the interdisciplinary Faculty Working Group in Political Economy of the Institute for Research in Social Science at Chapel Hill. 